Review article

\title{
Cobalt in athletes: hypoxia and doping - new crossroads
}

\author{
Anatoly V. Skalny ${ }^{1,2,3}$, Irina P. Zaitseva ${ }^{2}$, Yordanka G. Gluhcheva ${ }^{4}$, Andrey A. Skalny ${ }^{1}$, \\ Evgeny E. Achkasov ${ }^{5}$, Margarita G. Skalnaya ${ }^{1}$, Alexey A. Tinkov ${ }^{1,2}{ }^{*}$ \\ ${ }^{1}$ Peoples' Friendship University of Russia (RUDN University), Moscow, Russia \\ ${ }^{2}$ Yaroslavl State University, Yaroslavl, Russia \\ ${ }^{3}$ All-Russian Research Institute of Medicinal and Aromatic Plants, Moscow, Russia \\ ${ }^{4}$ Bulgarian Academy of Sciences, Institute of Experimental Morphology, Pathology and Anthropology with Museum, Sofia, Bulgaria \\ ${ }^{5}$ I. M. Sechenov First Moscow State Medical University, Moscow, Russia
}

\section{Abstract}

Cobalt is an essential trace element that is known to mimic hypoxia and hypoxic training. Inorganic Co compounds are capable of Hypoxiainducible factor-1 (HIF-1) activation, resulting in up-regulation of gene expression including erythropoietin (Epo). Experimental studies have demonstrated that Co treatment may increase hypoxic tolerance of different tissues, improve muscle metabolism and exercise performance. Other mechanisms may also involve modulation of steroid hormone and iron metabolism. Based on these experimental studies, in 2017 inorganic cobalt compounds were added into the World Anti-Doping Agency (WADA) prohibited list as doping agents. However, the existing data on beneficial effects of cobalt on exercise performance in athletes are scarce. Similarly, only experimental studies demonstrated exercise-induced decrease in tissue Co levels, whereas human data are inconsistent. In addition, multiple studies have demonstrated that excessive Co intake may be toxic due to prooxidant, proinflammatory, and proapoptotic activity. Therefore, monitoring of Co deficiency and overload is required to prevent potential health hazards in athletes. At the same time, modulation of Co status should be performed through supplementation avoiding excessive doses of inorganic cobalt that are used for doping and are accompanied by adverse health effects of metal toxicity.
\end{abstract}

Keywords: Cobalt; Doping; Hypoxia; Iron metabolism; Performance

\section{Introduction}

Adequate physical activity is essential for human health especially in view of the recent sedentary lifestyle (Powell et al., 2011). In particular, a significant association between physical activity and mental (Biddle and Asare, 2011), cardiovascular (Kohl, 2001), and metabolic health (Ford et al., 2005) was demonstrated. Moreover, physical activity and exercise were considered as potential contributors to population health (Khan et al., 2012). Elite sport also plays a significant role in regulation of national wellbeing through involvement of higher number of people in physical activity and its popularization (Grix and Carmichael, 2012). However, at personal level, extreme exercise may be associated with certain adverse health effects including traumas (Helenius et al., 2005), as well as cardiovascular (Maron and Pelliccia, 2006), respiratory diseases (Kippelen et al., 2012), nutritional disorders (Martinsen and Sundgot-Borgen, 2013).

Micronutrient (vitamin, mineral, trace element) deficiencies were found to be common in elite athletes due to increased requirements as well as imbalanced nutrition (Volpe, 2007). In particular, it has been demonstrated that iron deficiency and iron-deficiency anemia is rather common in athletes (Rowland, 2012; Zaitseva et al., 2017). Earlier studies also demonstrated deficiency of zinc (De Carvalho et al., 2012) and magnesium (Nielsen and Lukaski, 2006; Volpe, 2015) in athletes. Female athletes seem to be at higher risk of nutritional deficiencies (Gabel, 2006; McClung, 2012). The observed deficiencies may significantly decrease physical performance (Lukaski, 2004) through impairment of skeletal integrity (Medeiros, 2016), immunity (Gleeson et al., 2001), and other systems. In this regard, micronutrient supplementation was shown to be widespread in athletes, especially when diet is not able to cover all requirements (Misner, 2006). In particular, it has been demonstrated that vitamins and minerals are used by $84 \%$ and $73 \%$ of athletes, respectively (Maughan et al., 2007).

At the same time, the efficiency of uncontrolled supplementation seems to be questionable (Schwenk and Costley, 2002). In particular, beneficial effects of certain supplements were not demonstrated (Maughan et al., 2007). Moreover, some of the supplements may be harmful in case of misuse (Bonci, 2009; Zoller and Vogel, 2004).

Cobalt is an essential trace element that is also known to be used by athletes due to its ability to mimic hypoxia and hypoxic training (Lippi et al., 2006a). Moreover, cobalt com-

\footnotetext{
* Author for correspondence: Alexey A. Tinkov, Yaroslavl State University, Sovetskaya, 14, Yaroslavl 150003, Russia; e-mail: tinkov.a.a@gmail.com http://doi.org/10.32725/jab.2018.003

Submitted: 2018-03-26 • Accepted: 2018-10-15 • Prepublished online: 2018-11-23

J Appl Biomed 17/1: 21-28 • EISSN 1214-0287 • ISSN 1214-021X

(c) 2018 The Authors. Published by University of South Bohemia in České Budějovice, Faculty of Health and Social Sciences.

This is an open access article under the CC BY-NC-ND license.
} 
pounds were added into the WADA prohibited list as doping agents in 2017 (WADA Prohibited List, 2017). At the same time, the existing data on beneficial effects of cobalt on exercise performance are missing.

The majority of biological effects of Co are mediated by its biologically active form, cyanocobalamin (vitamin $\mathrm{B}_{12}$ ) (Yama$\mathrm{da}, 2013$ ) playing multiple functions in the organism including DNA synthesis regulation (Green et al., 2017; O’Leary and Samman, 2010).

Therefore, the primary objective of the study was to review the existing data on the interaction between cobalt metabolism and physical activity, the use of cobalt supplements and its effect on performance, as well as the potential mechanisms of the effects of inorganic cobalt $\left(\mathrm{Co}^{2+}\right)$.

\section{General aspects of cobalt kinetics}

Adult human organism contains approximately 1.1-1.5 mg cobalt. Liver is the main cobalt depot, containing up to $10 \%$ (0.11 mg) of the total level (Oberleas et al., 2008; WHO, 2006).
Under chronic exposure cobalt accumulates predominantly in blood, liver, kidneys, spleen and less in bones, testes and brain (Leggett, 2008) (Fig. 1). Understanding of cobalt kinetics after acute or chronic exposure is strongly required for adequate monitoring of cobalt exposure, especially due to its presence in WADA prohibited list (Unice et al., 2012).

Gastrointestinal absorption of water-soluble cobalt compounds is rather variable, depending on its chemical form, dose, as well as its relation to food intake (Harrison et al., 2001; Leggett, 2008). Efficiency of Co absorption varies from $18 \%$ to $97 \%$ depending on various factors (WHO, 2006). It is expected that gastrointestinal absorption of cobalt is at least partially mediated by mechanisms of iron transport (Barany et al., 2005). This supposition is supported by the observation of increased Co absorption in iron-deficiency (Leggett, 2008), as well as reduction of iron absorption after high-dose cobalt ingestion (Oberleas et al., 2008), suggesting a strong inverse relationship between Fe status and cobalt (Barany et al., 2005).

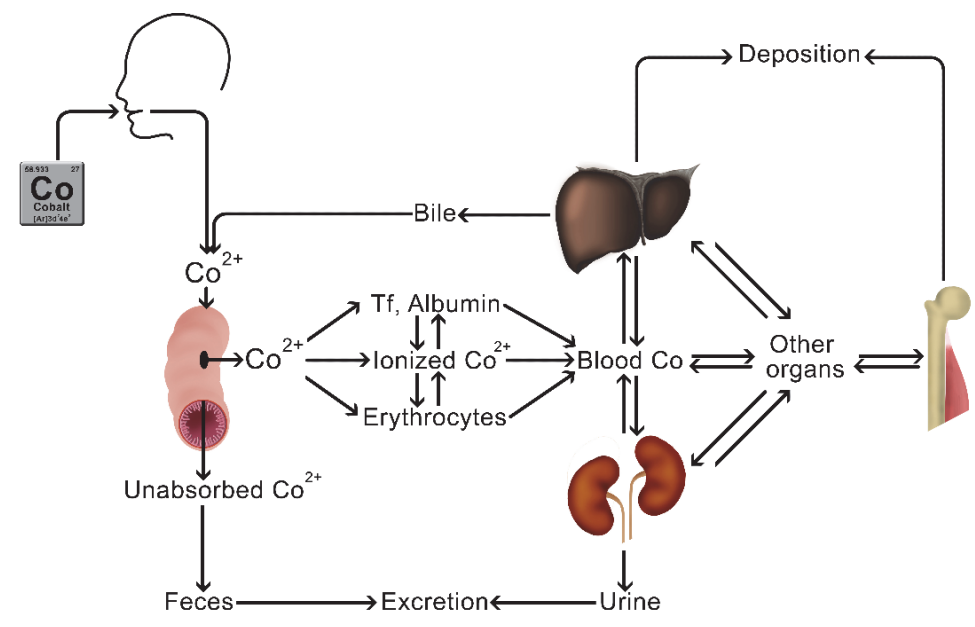

Fig. 1. Cobalt kinetics in the human organism

Efficiency of Co absorption varies from $18 \%$ to $97 \%$ depending on its chemical form, dose, as well as its relation to food intake. Divalent metal transport 1 (DMT1) and ferroportin may play a role in intestinal Co absorption. Under chronic exposure cobalt accumulates predominantly in blood, kidneys, spleen, liver (depot), and less in bones, testes and brain. The main mechanism of cobalt removal is its urinary excretion that may be used as biomarker for occupational exposure.

Divalent metal transport 1 (DMT1) may mediate apical cobalt absorption (Gunshin et al., 1997). In particular, strong affinity of Co ions to DMT1, although being lower than that for iron, was demonstrated (the affinity decreases in the order $\mathrm{Cd}^{2+}>\mathrm{Fe}^{2+}>\mathrm{Co}^{2+}, \mathrm{Mn}^{2+}>>\mathrm{Ni}^{2+}, \mathrm{VO}^{2+}, \mathrm{Zn}^{2+}$ ) (Illing et al., 2012). Other mechanisms involved in iron transport were also shown to be involved in Co metabolism. Particularly, recent studies have demonstrated that ferroportin (Fpn) also increases $\mathrm{Co}$ excretion. The role of ferroportin in Co transport is confirmed by the observation of down-regulation of Co excretion by hepcidin, a negative Fpn regulator (Mitchell et al., 2014). In turn, $\mathrm{Co}$ also regulates hepcidin signaling. Particularly, $\mathrm{CoCl}_{2}$ exposure inhibits hepcidin expression (Kawabata, 2017) and may not involve HIF 1 (Braliou et al., 2008).

In blood cobalt is transported in complex with albumin, as well as transferrin, lipoproteins and haptoglobin (Neilsen et al., 1998), whereas unbound fraction represents $5-12 \%$ of total Co (Simonsen et al., 2012). Co transport into erythrocyte is tightly associated with Ca metabolism, being transported via A23187 calcium ionophore (Simonsen et al., 2011). It has been demonstrated that P1B type ATPases also take part in cobalt transport (Zielazinski et al., 2012).
The main mechanism of cobalt removal is its urinary excretion (Oberleas et al., 2008). At the same time, the intensity of urinary Co excretion is non-linear, being high in the early period of exposure (several days) with a subsequent decrease (several weeks) (Simonsen et al., 2012). Urinary Co concentration is a biomarker for occupational exposure (Catalani et al., 2012) with a rapid increase in the first hours after exposure, and a peak at $3 \mathrm{~h}$ postexposure (Apostoli et al., 1994). At the same time, it is notable that excessive $B_{12}$ supplementation does not result in a significant dose-dependent increase in urinary $B_{12}$ (Fukuwatari et al., 2009).

\section{Cobalt status in athletes}

Despite the presence of multiple studies of biological effects of cobalt, its potential as doping, and inclusion into WADA prohibited list, data on cobalt metabolism in athletes are insufficient.

In particular, Marathon race did not result in a significant alteration of whole blood cobalt levels as compared to the baseline in runners (Berger et al., 2002). Similarly, exercise of various intensity did not affect Co plasma levels. Moreover, no significant changes were observed in 7 minutes after exercise 
(Soria et al., 2016). Similarly, no significant difference between pre- and post-exercise salivary Co levels was detected in volunteers performing a cycle ergometer test (Chicharro et al., 1999). It has been demonstrated that nocturnal exhaustion exercise was associated with a significant elevation of blood Co levels (Patlar et al., 2014). At the same time, assessment of post-exercise cobalt levels may not be indicative of its body burden, as physical activity usually induces redistribution of trace elements (as well as other biologically active substances) within the organism.

Assessment of hair Co content in professional football players demonstrated that cobalt levels in athletes significantly exceeded the control values. Moreover, athletes with low physical working capacity (PWC170) are characterized by more than two-fold lower hair Co content as compared to those with high PWC170 values (Skalny, 2005). At the same time, more than eight-fold decrease in hair Co levels was detected in wrestlers in comparison to the controls (Radysh and Dulepova, 2006).

Earlier we have demonstrated a significant positive relationship ( $p=0.042$ ) between physical activity and hair Co content in women, whereas in men such an association was only nearly significant $(p=0.066)$. At the same time, in men with low physical activity hair Co levels were more than two-fold lower as compared to physically active examinees (Zaitseva et al., 2015b). However, no significant activity-related group difference in whole blood Co levels was revealed both in men and women (Zaitseva et al., 2015a).

We have also demonstrated the deficiency of hair Co levels in children with low functional reserves (Detkov et al., 2013). Similar findings were made in younger schoolgirls with physical retardation aged 7-8 years (Svyatova et al., 2015).

Experimental studies have demonstrated that treadmill running resulted in a $28 \%$ decrease in liver and serum Co levels as compared to the control values in rats. At the same time, no significant group difference was detected in other tissues including skeletal and cardiac muscle, liver, and hair (Skalny et al., 2017). These data correspond to the study by Ergen et al. (2013) who demonstrated that strenuous exercise resulted in a significant decrease in frontal lobe, liver, and spleen Co levels, whereas moderate exercise reduced metal levels in brain stem, liver, and spleen (Ergen et al., 2013). Hepatic Co levels were also reduced in rats exposed to strenuous swimming exercise (Sivrikaya et al., 2013). Oppositely, swimming in rats resulted in a significant increase in serum cobalt levels, being attenuated by resveratrol treatment (Baltaci et al., 2017).

Interesting data were obtained during investigation of the biological effects of "Cobazol" (tetravinylimidazol cobalt dichloride) possessing protective antihypoxic activity (Babaniyazova, 2010). In particular, cobazol-treated animals were characterized by higher work capacity during running and swimming both in normoxic and hypoxic conditions (Lebedeva et al., 2010).

It has been also demonstrated that vitamins E (Patlar et al., 2011a) and A (Patlar et al., 2011b) supplementation significantly increased blood Co levels in athletes.

\section{Mechanisms of physiological function}

Cobalt was shown to mimic hypoxia due to its ability to induce hypoxia-inducible factor (HIF) in normoxic conditions (Simonsen et al., 2012). The oxygen sensing process involves a heme protein which incorporates $\mathrm{Co}$, substituting iron in the porphyrin ring (Bunn et al., 1998). Since cobalt heme binds oxygen with extremely low affinity, the oxygen sensor containing cobalt generates decreased levels of reactive oxygen species
(ROS) (Görlach et al., 1994), mimicking hypoxic environment and activating HIF-1. HIF is the key regulator of metabolic response to hypoxia activating gene expression (more than 300) including erythropoietin (Epo) (Wang and Semenza, 1993a, b). Oxygen-independent HIF activation is considered to be a perspective tool for tissue protection (Bernhardt et al., 2007).

HIFs are heterodimers consisting of HIF-alpha ( $\mathrm{HIF} \alpha)$ constitutive and HIF-beta (HIF $\beta$ ) subunits. HIF-1a is oxygen sensitive unit being expressed under hypoxic conditions and is present only in deoxygenated cells (Bunn et al., 1998). Hypoxia-induced HIF activation requires protection of its a subunit from ubiquitin-dependent proteolysis possibly by a mechanism that involves phosphorylation (Bunn et al., 1998). Hypoxia stabilizes $\mathrm{HIF}$, inducing its dimerization with the $\beta$-subunit and translocation to the nucleus to regulate transcription through binding the hypoxia-responsive element located in the target genes (Terraneo and Samaja, 2017; Xu et al., 2017). HIF-1 plays a key regulatory role in energy metabolism, angiogenesis, erythropoiesis, being also involved in the pathophysiology of cancer, inflammation, and ischemia (Xia et al., 2009).

Up-regulation of Epo gene requires assembling of several transcription factors - HIF1 $\alpha$ and hepatic nuclear factor 4 (HNF-4), which bind to the enhancer region of the Epo gene in response to reduced oxygen supply (Bunn et al., 1998). Enhanced Epo production results in stimulated erythropoiesis and neuroprotection.

As hypoxia-mimicking agent $\mathrm{CoCl}_{2}$ is used for long-term maintenance of hypoxic conditions in vitro. Co supplementation induces expression of various stem cell markers, being indicative of the potential use of $\mathrm{Co}$ in regenerative medicine for maintaining stem cell stemness (Osathanon et al., 2015). Preconditioning of bone mesenchymal stem cells (BMSCs) with $\mathrm{CoCl}_{2}$ activated $\mathrm{HIF} 1 a$, enhanced cell migration in vitro and thus may be used for development of the new therapeutic strategies for organ recovery after injury (Dai et al., 2017; Yu et al., 2013).

Earlier studies have demonstrated that oral cobalt chloride supplementation results in increased brain tolerance to hypoxia (Shrivastava et al., 2008b). In particular, cobalt-induced activation of HIF with subsequent erythropoietin production by astrocytes provides a significant protection to neurons in low-oxygen and low-carbohydrate conditions (Jones et al., 2013). Adaptation to hypoxia is possibly orchestrated by complex interplay of oxygen-sensing molecules including Epo, Epo receptor (EpoR), neuroglobin, neurotrophins, etc., being expressed in brain (Terraneo and Samaja, 2017).

Oral cobalt supplementation in animals resulted in an increased myocardial contractile function as compared to the control animals in ischemia-reoxygenation. These effects were associated with increased GluT1 and vascular endothelial growth factor (VEGF) expression (Endoh et al., 2000). The latter is in agreement with the later revealed HIF-dependent cobalt-induced angiogenesis in kidneys (Tanaka et al., 2005). Correspondingly, it has been demonstrated that Co administration in exercised rats significantly increases the number of VEGF-positive capillaries but does not induce microvascular remodeling in muscles (Suzuki, 2004). One of the mechanisms of protective effects of cobalt is decreased ROS and reactive nitrogen species (RNS) production due to increased heme oxygenase 1 and metallothionein levels, being mediated through HIF-induced signaling (Shrivastava et al., 2008a), as well as inhibition of nuclear factor- $\mathrm{B}(\mathrm{NF}-\mathrm{\kappa B})$ signaling and subsequent decrease in proinflammatory response (Oh et al., 2014). 
In line with increased erythropoietin production and hypoxic tolerance, a part of biological effects of cobalt takes place directly in skeletal muscle. Particularly, cobalt pretreatment in laboratory animal's results in more than twofold (non-exercised) and threefold (exercised) increase in exercise performance as compared to the control animals. Moreover, a significant activation of citric acid cycle and glycolytic enzymes, cytochrome c oxidase, as well as GluT1 expression, was also revealed. Activation of mitochondrial biogenesis was also observed, being associated with increased nitric oxide production (Saxena et al., 2012). In addition, increased performance under cobalt treatment is dose-dependent. In particular, exercised animals were characterized by a nearly three-fold increase in time to exhaustion as compared to the control values. Supplementation of exercised animals with 2.5 and $5 \mathrm{mg}$ / $\mathrm{kg}$ cobalt did not affect performance significantly. However, administration of 10 and $25 \mathrm{mg} / \mathrm{kg}$ cobalt resulted in a nearly $30 \%$ and $50 \%$ increase in time to exhaustion as compared to exercised animals. Further increase in the dose of cobalt tended to decrease the value (Saxena et al., 2010). Therefore, it can be proposed that cobalt supplementation in non-toxic doses may mimic hypoxia and increase hypoxic adaptation. Understanding the Co-induced alterations in oxygen sensing proteins as well as hypoxic signal transduction pathways will contribute to the elucidation of the biological role of cobalt in cellular adaptation to hypoxia.

It has been also demonstrated that Co-induced hypoxic signaling resulted in autophagy and atrophy in C2C12-derived mouse myotubes via the HIF-1a/BNIP3/beclin-1 and AMPK/ mTOR signaling pathways (Chen et al., 2017).

Cobalt effects on the skeletal muscles may be also associated with its ability to bind myoglobin. The formed complex Co-myoglobin has a smaller affinity to oxygen than Fe-myoglobin. Generation of Co-substituted myoglobin is used in designing artificial myoglobin-based oxygen carriers (Neya et al., 2014). In addition, cobalt preconditioning also affects other key networks, including lipid metabolism and cell cycle regulation (Ahmad et al., 2016).

Cobalt is also known to have a significant effect on steroid hormone metabolism. Due to its effect on cytochrome enzymes Co supplements are frequently prescribed to improve the therapeutic effect of hormone replacement therapy in menopausal and post-menopausal women to reduce estrogen hyperexcretion (Wright, 2005). Co inhibited progesterone and increased insulin-like growth factor I in a dose-dependent manner in rat ovarian fragments and Leydig tumor-derived MA-10 cells (Kumar et al., 2014; Roychoudhury et al., 2014). In addition, hypoxia reduced testosterone release in mouse Leydig cells (Wang et al., 2017).

Modulation of iron homeostasis may also at least partially mediate the effects of cobalt. In particular, available data demonstrate that cobalt chloride-induced hypoxic signalling activated transferrin receptor (TfR) gene transcription in hepatoma cells due to the HIF-1 binding site in the TfR promoter (Tacchini et al., 1999). Therefore, the potential "beneficial" mechanisms of Co supplementation may include activation of HIF-1 and downstream signaling including up-regulation of Epo gene expression, as well as modulation of muscle bioenergetics, iron and steroid hormone metabolism.

\section{Toxicity}

Despite its essentiality, acute or chronic exposure to high doses of cobalt may induce toxic effects. It is estimated that cobalt may induce oxidative stress due to both ROS overproduction and depression of antioxidants including reduced glutathione
(GSH) and ascorbate (Jomova and Valko, 2011), ultimately leading to oxidative damage to macromolecules including DNA (Alarifi et al., 2013). It has been also noted that excessive cobalt exposure results in impaired DNA reparation mechanisms especially in combination with toxic metals (Hengstler et al., 2003). Cobalt affinity to sulfhydryl groups is accompanied by inhibition of a number of enzymes, including those catalyzing tissue respiration (Simonsen et al., 2012). The ability of cobalt to induce apoptotic signaling was also demonstrated (Akbar et al., 2011). In line with induction of oxidative stress, cobalt was also capable of stimulation of proinflammatory milieu through proinflammatory cytokine overproduction, migration of immunocompetent cells via activation of Toll-like receptors 4 (TLR4) (Lawrence et al., 2016). Although cobalt-induced activation of HIF-1, being redox- and metal-sensitive transcription factor is considered as the key mechanism of physiological effect of cobalt, this process may also mediate certain toxic effects of cobalt exposure (Maxwell and Salnikow, 2004). In particular, a role of HIF-1 activation in cobalt cytotoxicity and proinflammatory effect has been demonstrated (Nyga et al., 2015). Studies show elevated blood and urine Co concentrations following hip and knee arthroplasty as well as delayed hypersensitivity reactions, osteolysis, pseudotumour formation, metallosis, local tissue inflammationand necrosis, although other metals including $\mathrm{Cr}$ were also found to be higher (Friesenbichler et al., 2014). In human and experimental animals chronic oral exposure to Co induces cardiomyopathy (Mosier et al., 2016), polyneuropathy, haematological, respiratory, thyroid gland and reproductive dysfunctions (Leyssens et al., 2017). Epidemiological studies show higher incidence of "goiter" in regions with increased water and soil Co levels. Experimental data reveal its genotoxicity caused by oxidative DNA damage and inhibition of DNA repair leading to carcinogenesis (Kinobe, 2016). Available pharmacokinetic data demonstrate that intravenously administered cobalt has a long elimination half-life (42-156 h) and a large volume of distribution $(0.94 \mathrm{l} / \mathrm{kg})$ in a horse implying that repeated administration of cobalt would accumulate in tissues over time attaining equilibrium after $~ 9-33$ days (Kinobe, 2016). Therefore, similar mechanisms may be involved in both cobalt essentiality and toxicity.

\section{Legislative and biological limitations for using cobalt as a doping}

In agreement with the above-mentioned mechanisms of cobalt activity, there is an increasing interest for its use as doping (Lippi et al., 2006b). In parallel with its biological activity, cobalt compounds are cheap, easily available, and comfortably used (Jozkow, 2017), that increases the possibility of its use as doping (Jelkmann and Lundby, 2011). Moreover, a detailed investigation of erythropoietic drugs being available on the Internet demonstrated that the majority of them contain non-described cobalt and/or nickel compounds (Thevis et al., 2016). In this regard, cobalt like other HIF stabilizers (molidustat) and activators (argon, xenon) was included into the official WADA prohibited list. At the same time, in the last edition of the List it is underlined that Co-containing $B_{12}$ is not a prohibited substance (WADA Prohibited List, 2017).

Despite the fact that cobalt-containing drugs have been only recently added to the WADA prohibited list (WADA Prohibited list, 2017), the methods of cobalt intake monitoring like urinary cobalt detection (Krug et al., 2014; Minakata et al., 2008) were developed earlier, as the potential of cobalt as doping has been discussed for a long time (Lippi et al., 2006b). In particular, inductively-coupled plasma mass-spectrometry 
(ICP-MS) is the method of choice for urinary Co assessment (Schänzer and Thevis, 2017).

Excessive cobalt consumption may result in adverse health effects, including gastrointestinal, heart, liver, thyroid, sensory damage. These effects should prevent athletes from using cobalt compounds as doping (Ebert and Jelkmann, 2014). In particular, when cobalt concentration in blood is less than $300 \mu \mathrm{g} / \mathrm{l}$, no adverse health effects are observed. However, within the range of 300-700 $\mu \mathrm{g} / 1$ significant hematological disorders including polycytemia, as well as altered thyroid iodine uptake may take place. At higher blood Co levels (>700 $\mu \mathrm{g} / \mathrm{l})$, neurological, reproductive, and cardiac disorders may be observed (Finley et al., 2012).

\section{The use of cobalt in equine sports and its limitations}

Cobalt has also been used in horses to increase performance (Ho et al., 2015). However, despite the presence of multiple indications of the use of cobalt as doping in horseracing, direct indications of the positive effect of cobalt on equine performance or other physiological parameters seem to be missing (Kinobe, 2016). At the same time, it has been demonstrated that single dose of cobalt in horses does not have any significant effect on Epo concentration or erythrocyte parameters (Knych et al., 2015). Moreover, a recent study demonstrated direct adverse effects of cobalt injections on cardiovascular system in horses. In particular, it has been revealed that Co infusion resulted in tachycardia, hypertension, muscle tremors, as well as elevation of Adrenocorticotropic hormone, cortisol, and troponin I levels (Burns et al., 2017), that may subsequently result in cardiac arrest and death (Mobasheri and Proudman, 2015).

Therefore, the thresholds of $100 \mathrm{ng} / \mathrm{ml}$ cobalt in urine and $50 \mathrm{ng} / \mathrm{ml}$ in plasma have been set by the International Federation of Horseracing Authorities and the Racing Commissioners International, respectively (Brewer et al., 2016). Urinary and plasma levels of Co were also proposed to be included into the biological passport of the equine athletes (Cawley and Keledjian, 2017). For the purpose of biomonitoring, it has been proposed that the cobalt-to- $\mathrm{B}_{12}$ ratio in plasma and urine may be used to differentiate doping from supplementation (Hillyer et al., 2017).

\section{Conclusions}

The existing data demonstrate that $C o$ is an essential element, being toxic in increasing doses. Therefore, monitoring of cobalt and $B_{12}$ status of the organism, especially in athletes, is essential for maintenance of optimal Co status. As in the case of cobalt, it is impossible to clearly identify any particular patterns of $\mathrm{B}_{12}$ status in athletes. Thus, considering the physiological role of these micronutrients (Fig. 2), as well as evidence of insufficiency of their intake and disturbance of metabolic processes, the level of cobalt, cyanocobalamin, as well as metabolites of the latter should be carefully monitored. At the moment, urinary Co level is considered as the potential biomarker of Co abuse in athletes. Blood sampling may be also useful for monitoring of Co exposure in addition to other parameters associated with Co supplementation, including hemoglobin, $\mathrm{B}_{12}$, iron, cobalt, Epo and anabolic steroids. However, further studies are required for biomarker validation. Taking into account a narrow therapeutic range, as well as a wide spectrum of toxic effects, modulation of Co status should be performed through supplementation avoiding over nutritional doses of inorganic cobalt that are used for doping and are accompanied by adverse health effects of metal toxicity.

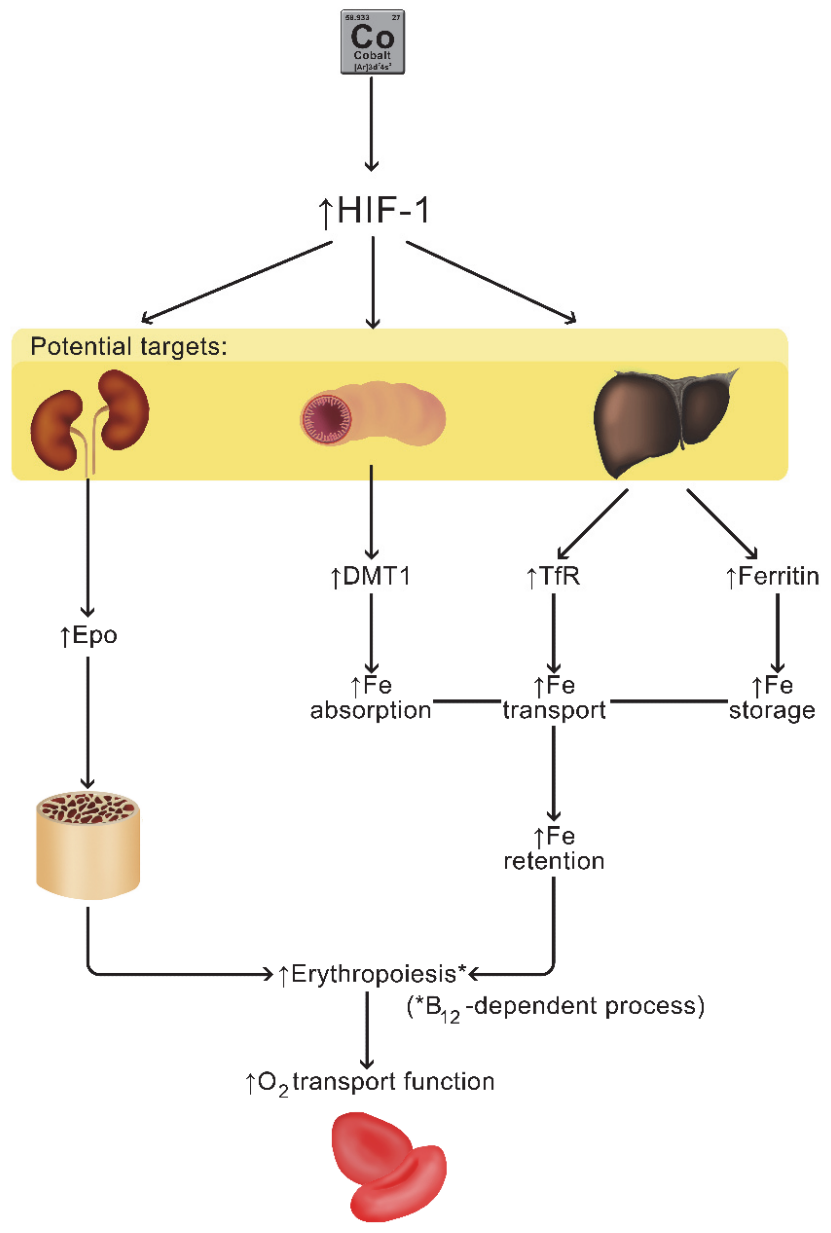

Fig. 2. Possible mechanisms and target organs of HIF-1-dependent physiological effects of cobalt on oxygen-transport function and iron metabolism

The majority of biological effects of cobalt are mediated through HIF-1 activation thus mimicking hypoxia. HIF-1 signaling in kidneys results in increased Epo production. Co-induced HIF-1 activation also plays a significant role in modulation of iron homeostasis through up-regulation of intestinal DMT1 and hepatic ferritin and transferrin expression, thus increasing Fe retention. Taken together, these changes may mediate increased erythropoiesis and oxygen-transport function.

\section{Conflict of interests}

The authors declare no conflict of interests.

\section{Acknowledgements}

The publication was prepared with the support of the "RUDN University Program 5-100".

\section{References}

Ahmad Y, Mishra S, Arya A, Paul S, Sharma M, Prasad J, Bhargava $\mathrm{K}$ (2016). Revisiting cobalt chloride preconditioning to prevent hypobaric hypoxia-induced damage: identification of global proteomic alteration and key networks. Funct Integr Genomics 16: 281-295. DOI: 10.1007/s10142-016-0483-2.

Akbar M, Brewer JM, Grant MH (2011). Effect of chromium and cobalt ions on primary human lymphocytes in vitro. J Immunotoxicol 8: 140-149. DOI: 10.3109/1547691X.2011.553845. 
Alarifi S, Ali D, Ao Y AM, Siddiqui MA, Al-Khedhairy AA (2013). Oxidative stress contributes to cobalt oxide nanoparticlesinduced cytotoxicity and DNA damage in human hepatocarcinoma cells. Int J Nanomedicine 189: 99. DOI: $10.2147 /$ IJN.S37924.

Apostoli P, Porru S, Alessio L (1994). Cobalt and Hard Metal Disease Urinary cobalt excretion in short time occupational exposure to cobalt powders. Sci Total Environ 150: 129-132.

Babaniyazova ZH (2010). Estimation of the biological activity of new cobalt metallocomplex. Trace Elem Med 11: 35-40.

Baltaci AK, Arslangil D, Mogulkoc R, Patlar S (2017). Effect of resveratrol administration on the element metabolism in the blood and brain tissues of rats subjected to acute swimming exercise. Biol Trace Elem Res 175: 421-427. DOI: 10.1007/ s12011-016-0792-2.

Barany E, Bergdahl IA, Bratteby LE, Lundh T, Samuelson G, Skerfving S, Oskarsson A (2005). Iron status influences trace element levels in human blood and serum. Environ Res 98: 215-223. DOI: 10.1016/j.envres.2004.09.010.

Berger CE, Kröner A, Kluger R, Baron R, Steffan I, Engel A (2002). Effects of marathon running on the trace minerals chromium, cobalt, nickel, and molybdenum. J Trace Elem Exp Med 15: 201-209. DOI: 10.1002/jtra.10019.

Bernhardt WM, Warnecke C, Willam C, Tanaka T, Wiesener MS, Eckardt KU (2007). Organ protection by hypoxia and hypoxiainducible factors. Methods Enzymol 435: 221-245. DOI: 10.1016/ S0076-6879(07)35012-X.

Biddle SJH, Asare M (2011). Physical activity and mental health in children and adolescents: A review of reviews. Br J Sports Med 45: 886-895. DOI: 10.1136/bjsports-2011-090185.

Bonci L (2009). Supplements: Help, harm, or hype? How to approach athletes. Curr Sports Med Rep 8: 200-205. DOI: 10.1249/ JSR.0b013e3181ae9ae8.

Braliou GG, Falzacappa MVV, Chachami G, Casanovas G, Muckenthaler MU, Simos G (2008). 2-Oxoglutarate-dependent oxygenases control hepcidin gene expression. J Hepatol 48: 801-810. DOI: 10.1016/j.jhep.2007.12.021.

Brewer K, Maylin GA, Fenger CK, Tobin T (2016). Cobalt use and regulation in horseracing: a review. Comp Exerc Physiol 12: 1-10. DOI: $10.3920 / C E P 140008$.

Bunn HF, Gu J, Huang LE, Park J-W, Zhu H (1998). Erythropoietin: a model system for studying oxygen-dependent gene regulation. J Exp Biol 201: 1197-1201.

Burns TA, Dembek KA, Kamr A, Dooley SB, Dunbar LK, Aarnes TK, et al. (2017). Effect of Intravenous Administration of Cobalt Chloride to Horses on Clinical and Hemodynamic Variables. J Vet Intern Med 32: 441-449. DOI: 10.1111/jvim.15029.

Catalani S, Rizzetti MC, Padovani A, Apostoli P (2012). Neurotoxicity of cobalt. Hum Exp Toxicol 31: 421-437. DOI: $10.1177 / 0960327111414280$.

Cawley AT, Keledjian J (2017). Intelligence-based anti-doping from an equine biological passport. Drug Test Anal 9: 1441-1447. DOI: $10.1002 /$ dta. 2180.

Chen R, Jiang T, She Y, Xu J, Li C, Zhou S, et al. (2017). Effects of cobalt chloride, a hypoxia-mimetic agent, on autophagy and atrophy in skeletal C2C12 myotubes. Biomed Res Int. DOI: $10.1155 / 2017 / 7097580$

Chicharro JL, Serrano V, Ureña R, Gutierrez AM, Carvajal A, Fernandez-Hernando P, Lucia A (1999). Trace elements and electrolytes in human resting mixed saliva after exercise. Br J Sports Med 33: 204-207. DOI: 10.1136/bjsm.33.3.204

Dai Y, Li W, Zhong M, Chen J, Cheng Q, Liu Y, Li T (2017). The paracrine effect of cobalt chloride on BMSCs during cognitive function rescue in the HIBD rat. Behav Brain Res 33: 99-109. DOI: 10.1016/j.bbr.2017.05.055.

De Carvalho FG, Rosa FT, Suen VMM, Freitas EC, Padovan GJ, Marchini JS (2012). Evidence of zinc deficiency in competitive swimmers. Nutrition 28: 1127-1131. DOI: 10.1016/j. nut.2012.02.012.

Detkov VYu, Skalny AV, Karganov MYu, Cherepov AB, Medvedeva YuS, Glazov MYu, Isankina LN (2013). Deficiency of cobalt in children with a low functional reserve. Technol Liv Syst 10: 22-28.
Ebert B, Jelkmann W (2014). Intolerability of cobalt salt as erythropoietic agent. Drug Test Anal 6: 185-189. DOI: 10.1002/ dta.1528.

Endoh H, Kaneko T, Nakamura H, Doi K, Takahashi E (2000). Improved cardiac contractile functions in hypoxia-reoxygenation in rats treated with low concentration Co2+. Am J Physiol Heart Circ Physiol 279: H2713-H2719. DOI: 10.1152/ ajpheart.2000.279.6.H2713.

Ergen K, Ince H, Düzova H, Karakoç Y, Emre MH (2013). Acute effects of moderate and strenuous running on trace element distribution in the brain, liver, and spleen of trained rats. Balkan Med J 30: 105. DOI: 10.5152/balkanmedj.2012.093.

Finley BL, Monnot AD, Gaffney SH, Paustenbach DJ (2012). Doseresponse relationships for blood cobalt concentrations and health effects: a review of the literature and application of a biokinetic model. J Toxicol Environ Health B Crit Rev 15: 493-523. DOI: $10.1080 / 10937404.2012 .744287$.

Ford ES, Kohl HW, Mokdad AH, Ajani UA (2005). Sedentary behavior, physical activity, and the metabolic syndrome among US adults. Obes Res 13: 608-614. DOI: 10.1038/oby.2005.65.

Friesenbichler J, Sadoghi P, Maurer-Ertl W, Szkandera J, Glehr $\mathrm{M}$, Ogris K, et al. (2014). Serum metal ion concentrations in paediatric patients following total knee arthroplasty using megaprostheses. Biomed Res Int 2014: 817257. DOI: $10.1155 / 2014 / 817257$

Fukuwatari T, Sugimoto E, Tsuji T, Hirose J, Fukui T, Shibata K (2009). Urinary excretion of vitamin B12 depends on urine volume in Japanese female university students and elderly. Nutr Res 29: 839-845. DOI: 10.1016/j.nutres.2009.10.008

Gabel KA (2006). Special nutritional concerns for the female athlete. Curr Sports Med Rep 5: 187-191. DOI: 10.1097/01. CSMR.0000306505.78729.fb.

Gleeson M, Lancaster GI, Bishop NC (2001). Nutritional strategies to minimise exercise-induced immunosuppression in athletes. Can J Appl Physiol 26: S23-S35. DOI: 10.1139/h2001-039.

Görlach A, Fandrey J, Holtermann G, Acker H (1994). Effects of cobalt on haem proteins of erythropoietin-producing HepG2 cells in multicellular spheroid culture. FEBS Lett 348: 216-218. DOI: 10.1016/0014-5793(94)00607-5.

Green R, Allen L H, Bjørke-Monsen AL, Brito A, Guéant JL, Miller JW, et al. (2017). Vitamin B12 deficiency. Nat Rev Dis Primers 3: 17040. DOI: $10.1038 /$ nrdp.2017.40.

Grix J, Carmichael F (2012). Why do governments invest in elite sport? A polemic. Int J Press/Politics 4: 73-90. DOI: 10.1080/19406940.2011.627358.

Gunshin H, Mackenzie B, Berger UV, Gunshin Y, Romero MF, Boron WF, et al. (1997). Cloning and characterization of a mammalian proton-coupled metal-iontransporter. Nature 388: 482-488. DOI: $10.1038 / 41343$.

Harrison JD, Metivier H, Leggett RW, Nosske D, Paquet F, Phipps A, et al. (2001). Reliability of the ICRP's dose coefficients for members of the public. II. Uncertainties in the absorption of ingested radionuclides and the effect on dose estimates. Radiat Prot Dosimetry 95: 295-308.

Helenius I, Lumme A, Haahtela T (2005). Asthma, airway inflammation and treatment in elite athletes. Sports Med 35: 565-574.

Hengstler JG, Bolm-Audorff U, Faldum A, Janssen K, Reifenrath M, Götte W, et al. (2003). Occupational exposure to heavy metals: DNA damage induction and DNA repair inhibition prove coexposures to cadmium, cobalt and lead as more dangerous than hitherto expected. Carcinogenesis 24: 63-73. DOI: 10.1093/ carcin/bgg166.

Hillyer LL, Ridd Z, Fenwick S, Hincks P, Paine SW (2017). Pharmacokinetics of inorganic cobalt and a vitamin B12 supplement in the Thoroughbred horse: Differentiating cobalt abuse from supplementation. Equine Vet J 50: 343-349. DOI: 10.1111 evj.12774

Ho EN, Chan GH, Wan TS, Curl P, Riggs CM, Hurley MJ, Sykes D (2015). Controlling the misuse of cobalt in horses. Drug Test Anal 7: 21-30. DOI: 10.1002/dta.1719.

Illing AC, Shawki A, Cunningham CL, Mackenzie B (2012). Substrate profile and metal-ion selectivity of human divalent metal-ion 
transporter-1. J Biol Chem 287: 30485-30496. DOI: 10.1074/jbc. M112.364208.

Jelkmann W, Lundby C (2011). Blood doping and its detection. Blood 118: 2395-2404. DOI: 10.1182/blood-2011-02-303271.

Jomova K, Valko M (2011). Advances in metal-induced oxidative stress and human disease. Toxicology 283: 65-87. DOI: 10.1016/j. tox.2011.03.001.

Jones SM, Novak AE, Elliott JP (2013). The role of HIF in cobaltinduced ischemic tolerance. Neuroscience 252: 420-430. DOI: 10.1016/j.neuroscience.2013.07.060.

Jozkow P (2017). Drug Abuse, Doping, and Extreme Sports. In: Feletti F (Ed.). Extreme Sports Medicine. Springer, Cham, pp. 97-105.

Kawabata H (2017). Progress in iron metabolism research. Rinsho Ketsueki 58: 1864-1871. DOI: 10.11406/rinketsu.58.1864.

Khan KM, Thompson AM, Blair SN, Sallis JF, Powell KE, Bull FC, Bauman AE (2012). Sport and exercise as contributors to the health of nations. Lancet 380: 59-64. DOI: 10.1016/S01406736(12)60865-4.

Kinobe RT (2016). Towards the elimination of excessive cobalt supplementation in racing horses: A pharmacological review. Res Vet Sci 104: 106-112. DOI: 10.1016/j.rvsc.2015.12.007.

Kippelen P, Fitch KD, Anderson SD, Bougault V, Boulet LP, Rundell, et al. (2012). Respiratory health of elite athletes-preventing airway injury: a critical review. Br J Sports Med 46: 471-476. DOI: 10.1136/bjsports-2012-091056.

Knych HK, Arthur RM, Mitchell MM, Holser I, Poppenga R, Smith LL, et al. (2015). Pharmacokinetics and selected pharmacodynamics of cobalt following a single intravenous administration to horses. Drug Test Anal 7: 619-625. DOI: 10.1002/dta.1737.

Kohl HW (2001). Physical activity and cardiovascular disease: evidence for a dose response. Med Sci Sport Exer 33: S472-S483. DOI: 10.1097/00005768-200106001-00017.

Krug O, Kutscher D, Piper T, Geyer H, Schänzer W, Thevis M (2014). Quantifying cobalt in doping control urine samples-a pilot study. Drug Test Anal 6: 1186-1190. DOI: 10.1002/dta.1694.

Kumar A, Rani L, Dhole B (2014). Role of oxygen in the regulation of Leydig tumor derived MA-10 cell steroid production: the effect of cobalt chloride. Syst Biol Reprod Med 60: 112-118. DOI: 10.3109/19396368.2013.861034.

Lawrence H, Deehan DJ, Holland JP, Anjum SA, Mawdesley AE, Kirby JA, Tyson-Capper AJ (2016). Cobalt ions recruit inflammatory cells in vitro through human Toll-like receptor 4 . Biochem Biophys Rep 7: 374-378. DOI: 10.1016/j.bbrep.2016.07.003.

Lebedeva SA, Babaniyazova ZH, Babaniyazov HH, Portugalov SN (2010). The study of the combined action of metal-complex compounds derived vinylimidazole on physical performance. Bull, Bryansk State University 4: 1-3.

Leggett RW (2008). The biokinetics of inorganic cobalt in the human body. Sci Total Environ 389: 259-269. DOI: 10.1016/j. scitotenv.2007.08.054.

Leyssens L, Vinck B, Van Der Straeten C, Wuyts F, Maes L (2017). Cobalt toxicity in humans - A review of the potential sources and systemic. Toxicology 387: 43-56. DOI: 10.1016/j.tox.2017.05.015.

Lippi G, Franchini M, Guidi GC (2006a). Cobalt salts administration to athletes: a new treat? Doping J News. DOI: 10.1136/ bjsm.2005.019232.

Lippi G, Franchini M, Guidi GC (2006b). Blood doping by cobalt. Should we measure cobalt in athletes? J Occup Med Toxicol 1: 18. DOI: 10.1186/1745-6673-1-18.

Lukaski HC (2004). Vitamin and mineral status: effects on physical performance. Nutrition 20: 632-644. DOI: 10.1016/j. nut.2004.04.001.

Maron B J, Pelliccia A (2006). The heart of trained athletes: cardiac remodeling and the risks of sports, including sudden death. Circulation 114: 1633-1644. DOI: 10.1161/ CIRCULATIONAHA.106.613562.

Martinsen M, Sundgot-Borgen J (2013). Higher prevalence of eating disorders among adolescent elite athletes than controls. Med Sci Sports Exerc 45: 1188-1197. DOI: 10.1249/ MSS.0b013e318281a939.
Maughan RJ, Depiesse F, Geyer H (2007). The use of dietary supplements by athletes. J Sport Sci 25: S103-S113. DOI: $10.1080 / 02640410701607395$.

Maxwell P, Salnikow K (2004). HIF-1, an oxygen and metal responsive transcription factor. Cancer Biol Ther 3: 29-35. DOI: $10.4161 / \mathrm{cbt} .3 .1 .547$.

McClung JP (2012). Iron status and the female athlete. J Trace Elem Med Bio 26: 124-126. DOI: 10.1016/j.jtemb.2012.03.006.

Medeiros DM (2016). Copper, iron, and selenium dietary deficiencies negatively impact skeletal integrity: A review. Exp Biol Med (Maywood) 241: 1316-1322. DOI: 10.1177/1535370216648805.

Minakata K, Suzuki M, Suzuki O (2008). Application of electrospray ionization tandem mass spectrometry for the rapid and sensitive determination of cobalt in urine. Anal Chim Acta 614: 161-164. DOI: 10.1016/j.aca.2008.03.043.

Misner B (2006). Food alone may not provide sufficient micronutrients for preventing deficiency. J Int Soc Sport Nutr 3: 51. DOI: 10.1186/1550-2783-3-1-51.

Mitchell CJ, Shawki A, Ganz T, Nemeth E, Mackenzie B (2014). Functional properties of human ferroportin, a cellular iron exporter reactive also with cobalt and zinc. Am J Physiol Cell Physiol 306: 450-459. DOI: 10.1152/ajpcell.00348.2013.

Mobasheri A, Proudman CJ (2015). Cobalt chloride doping in racehorses: Concerns over a potentially lethal practice. Vet J 205: 335-338. DOI: 10.1016/j.tvjl.2015.04.005.

Mosier BA, Maynard L, Sotereanos NG, Sewecke JJ (2016). Progressive cardiomyopathy in a patient with elevated cobalt ion levels and bilateral metal-on-metal hip arthroplasties. Am J Orthop (Belle Mead, NJ) 45: 132-135.

Neilsen JL, Abildtrup A, Christensen J, Watson P, Cox A, McLeod CW (1998). Laser ablation inductively coupled plasma-mass spectrometry in combination with gel electrophoresis: a new strategy for speciation of metal binding serum proteins. Spectrochim Acta B At Spectrosc 53: 339-345. DOI: 10.1016/ S0584-8547(98)00077-9.

Neya S, Yonetani T, Kawaguchi AT (2014). Usefulness of myoglobin containing cobalt heme cofactor in designing a myoglobin-based artificial oxygen carrier. Artif Organs 38: 715-719. DOI: 10.1111/ aor.12327.

Nielsen FH, Lukaski HC (2006). Update on the relationship between magnesium and exercise. Magnes Res 19: 180-189. DOI: 10.1684/ mrh.2006.0060.

Nyga A, Hart A, Tetley TD (2015). Importance of the HIF pathway in cobalt nanoparticle-induced cytotoxicity and inflammation in human macrophages. Nanotoxicology 9: 905-917. DOI: 10.3109/17435390.2014.991430.

O'Leary F, Samman S (2010). Vitamin B12 in health and disease. Nutrients 2: 299-316. DOI: 10.3390/nu2030299.

Oberleas D, Harland B, Skalny A (2008). The biological role of macro and trace elements in humans and animals. St. Petersburg, Nauka, $544 \mathrm{p}$.

Oh SW, Lee YM, Kim S, Chin HJ, Chae DW, Na KY (2014). Cobalt chloride attenuates oxidative stress and inflammation through NF- $\kappa$ B inhibition in human renal proximal tubular epithelial cells. J Korean Med Sci 29: S139-S145. DOI: 10.3346/jkms.2014.29. S2.S139.

Osathanon T, Vivatbutsiri P, Sukarawan W, Sriarj W, Pavasant P, Sooampon S (2015). Cobalt chloride supplementation induces stem-cell marker expression and inhibits osteoblastic differentiation in human periodontal ligament cells. Arch Oral Biol 60: 29-36. DOI: 10.1016/j.archoralbio.2014.08.018

Patlar S, Boyali E, Baltaci AK, Mogulkoc R (2011b). The effect of vitamin A supplementation on various elements in elite taekwondo players. Biol Trace Elem Res 139: 296-300. DOI: 10.1007/s12011-010-8668-3.

Patlar S, Boyali E, Baltaci AK, Mogulkoc R, Gunay M (2011a). Elements in sera of elite taekwondo athletes: effects of vitamin E supplementation. Biol Trace Elem Res 139: 119-125. DOI: 10.1007/s12011-010-8648-7.

Patlar S, Gulnar U, Baltaci KA, Mogulkoc R (2014). Effect of nocturnal exhaustion exercise on the metabolism of selected elements. Arch Biol Sci 66: 1595-1601. DOI: 10.2298/ ABS1404595P. 
Powell KE, Paluch AE, Blair SN (2011). Physical activity for health: What kind? How much? How intense? On top of what? Annu Rev Public Health 32: 349-365. DOI: 10.1146/annurevpublhealth-031210-101151.

Radysh II, Dulepova II (2006). Features of the elemental composition of the hair wrestlers Greco-Roman style. Bull, PFUR Med 1: 28-33.

Rowland T (2012). Iron deficiency in athletes: an update. Am J Lifestyle Med 6: 319-327. DOI: 10.1177/1559827611431541.

Roychoudhury S, Sirotkin AV, Toman R, Kolesarova A (2014). Cobalt-induced hormonal and intracellular alterations in rat ovarian fragments in vitro. J Environ Sci Health B 49: 971-977. DOI: 10.1080/03601234.2014.951586.

Saxena S, Shukla D, Bansal A (2012). Augmentation of aerobic respiration and mitochondrial biogenesis in skeletal muscle by hypoxia preconditioning with cobalt chloride. Toxicol Appl Pharmacol 264: 324-334. DOI: 10.1016/j.taap.2012.08.033.

Saxena S, Shukla D, Khan YA, Singh M, Bansal A, Sairam M, Jain SK (2010). Hypoxia preconditioning by cobalt chloride enhances endurance performance and protects skeletal muscles from exercise-induced oxidative damage in rats. Acta Physiol (Oxf) 200: 249-263. DOI: 10.1111/j.1748-1716.2010.02136.x.

Schänzer W, Thevis M (2017). Human sports drug testing by mass spectrometry. Mass Spectrom Rev 36: 16-46. DOI: 10.1002/ mas. 21479.

Schwenk TL, Costley CD (2002). When food becomes a drug: nonanabolic nutritional supplement use in athletes. Am J Sport Med, 30: 907-916. DOI: 10.1177/03635465020300062701.

Shrivastava K, Ram MS, Bansal A, Singh SS, Ilavazhagan G (2008b). Cobalt supplementation promotes hypoxic tolerance and facilitates acclimatization to hypobaric hypoxia in rat brain. High Alt Med Biol 9: 63-75. DOI: 10.1089/ham.2008.1046.

Shrivastava K, Shukla D, Bansal A, Sairam M, Banerjee PK, Ilavazhagan G (2008a). Neuroprotective effect of cobalt chloride on hypobaric hypoxia-induced oxidative stress. Neurochem Int 52: 368-375. DOI: 10.1016/j.neuint.2007.07.005.

Simonsen LO, Harbak H, Bennekou P (2011). Passive transport pathways for $\mathrm{Ca} 2+$ and $\mathrm{Co} 2+$ in human red blood cells. $57 \mathrm{Co}$ 2+ as a tracer for Ca 2+ influx. Blood Cells Mol Dis 47: 214-225. DOI: 10.1016/j.bcmd.2011.09.002.

Simonsen LO, Harbak H, Bennekou P (2012). Cobalt metabolism and toxicology - a brief update. Sci Total Environ 432: 210-215. DOI: 10.1016/j.scitotenv.2012.06.009.

Sivrikaya A, Akil M, Bicer M, Kilic M, Baltaci AK, Mogulkoc R (2013). The effect of selenium supplementation on elements distribution in liver of rats subject to strenuous swimming. Bratisl Lek Listy 114: 12-14. DOI: 10.4149/BLL_2013_003.

Skalny AA, Medvedeva YS, Alchinova IB, Gatiatulina ER, Radysh IV, Karganov MY, et al. (2017). Zinc supplementation modifies trace element status in exercised rats. J Appl Biomed 15: 39-47. DOI: $10.1016 /$ j.jab.2016.09.007.

Skalny AV (2005). Physiological aspects of macro - and micronutrients in sport. Orenburg State University Publishing, Orenburg, $210 \mathrm{p}$.

Soria M, Anson M, Escanero JF (2016). Correlation Analysis of Exercise-Induced Changes in Plasma Trace Element and Hormone Levels During Incremental Exercise in Well-Trained Athletes. Biol Trace Elem Res 170: 55-64. DOI: 10.1007/s12011-015-0466-5.

Suzuki J (2004). Time-course changes in VEGF expression and capillarity in the early stage of exercise training with $\mathrm{Co} 2+$ treatment in rat skeletal muscles. Acta Physiol (Oxf) 181: 225-232. DOI: 10.1111/j.1365-201X.2004.01279.x.

Svyatova NV, Miftakhov SF, Miftakhov TF, Sidorova MN (2015). Morphofunctional rates of children on the background of the content of cobalt in the body. Curr Probl Sci Ed 2: 297.

Tacchini L, Bianchi L, Bernelli-Zazzera A, Cairo G (1999). Transferrin receptor induction by hypoxia. HIF-1-mediated transcriptional activation and cell-specific post-transcriptional regulation. J Biol Chem 274: 24142-24146. DOI: 10.1074/jbc.274.34.24142.

Tanaka T, Kojima I, Ohse T, Ingelfinger JR, Adler S, Fujita T, Nangaku M (2005). Cobalt promotes angiogenesis via hypoxia- inducible factor and protects tubulointerstitium in the remnant kidney model. Lab Invest 85: 1292-1307. DOI: 10.1038/ labinvest.3700328.

Terraneo L, Samaja M (2017). Comparative response of brain to chronic hypoxia and hyperoxia. Int J Mol Sci 18. DOI: 10.3390/ ijms18091914.

Thevis M, Krug O, Piper T, Geyer H, Schänzer W (2016). Solutions advertised as erythropoiesis-stimulating products were found to contain undeclared cobalt and nickel species. Int J Sports Med 37: 82-84. DOI: 10.1055/s-0035-1569350.

Unice KM, Monnot AD, Gaffney SH, Tvermoes BE, Thuett KA, Paustenbach DJ, Finley BL (2012). Inorganic cobalt supplementation: Prediction of cobalt levels in whole blood and urine using a biokinetic model. Food Chem Toxicol 50: 2456-2461. DOI: 10.1016/j.fct.2012.04.009.

Volpe SL (2007). Micronutrient requirements for athletes. Clin Sports Med 26: 119-130. DOI: 10.1016/j.csm.2006.11.009

Volpe SL (2015). Magnesium and the athlete. Curr Sports Med Rep 14: 279-283. DOI: 10.1249/JSR.0000000000000178.

WADA Prohibited List (2017). [online] [cit. 2018-10-11]. Available from: https://www.wada-ama.org/sites/default/files/resources/ files/2016-09-29_-_wada_prohibited_list_2017_eng_final.pdf

Wang GL, Semenza GL (1993a). General involvement of hypoxiainducible factor 1 in transcriptional response to hypoxia. Proc Natl Acad Sci U.S.A. 90: 4304-4308. DOI: 10.1073/pnas.90.9.4304.

Wang GL, Semenza GL (1993b). Characterization of hypoxiainducible factor 1 and regulation of DNA binding activity by hypoxia. J Biol Chem 268: 21513-21518.

Wang X, Pan L, Zou Z, Wang D, Lu Y, Dong Z, Zhu L (2017). Hypoxia reduces testosterone synthesis in mouse Leydig cells by inhibiting NRF1-activated StAR expression. Oncotarget 8: 16401-16413. DOI: 10.18632/oncotarget.14842.

WHO (2006). Cobalt and inorganic cobalt compounds. Concise International Chemical Assessment Document 69. WHO Press, Geneva.

Wright JV (2005). Bio-identical steroid hormone replacement: selected observations from 23 years of clinical and laboratory practice. ANN N Y Acad Sci 1057: 506-524. DOI: 10.1196/ annals.1356.039.

Xia M, Huang R, Sun Y, Semenza GL, Force Aldred S, Witt KL, et al. (2009). Identification of chemical compounds that induce HIF-1a activity. Toxicol Sci 112: 153-163. DOI: 10.1093/toxsci/kfp123.

Xu MM, Wang J, Xie JX (2017). Regulation of iron metabolism by hypoxia-inducible factors. Sheng Li Xue Bao 69: 598-610. DOI: $10.13294 /$ j.aps.2017.0054.

Yamada K (2013). Cobalt: its role in health and disease. Met Ions Life Sci 13: 295-320. DOI: 10.1007/978-94-007-7500-8_9.

Yu X, Lu C, Liu H, Rao S, Cai J, Liu S, et al. (2013). Hypoxic preconditioning with cobalt of bone marrow mesenchymal stem cells improves cell migration and enhances therapy for treatment of ischemic acute kidney injury. PLoS One 8: e62703. DOI: 10.1371/journal.pone.0062703.

Zaitseva IP, Skalny AA, Tinkov AA, Berezkina ES, Grabeklis AR, Nikonorov AA, Skalny AV (2015b). Blood essential trace elements and vitamins in students with different physical activity. Pakistan J Nutr 14: 721. DOI: 10.3923/pjn.2015.721.726.

Zaitseva IP, Skalny AA, Tinkov AA, Berezkina ES, Grabeklis AR, Skalny AV (2015a). The influence of physical activity on hair toxic and essential trace element content in male and female students. Biol Trace Elem Res 163: 58-66. DOI: 10.1007/s12011-0140172-8.

Zaitseva IP, Tinkov AA, Detkov VYu, Skalny AV (2017). State of iron metabolism during increased physical exertion. Probl Biol Med Pharm Chem 7: 35-45. DOI: 10.1007/s12011-014-0172-8.

Zielazinski EL, Cutsail III GE, Hoffman BM, Stemmler TL, Rosenzweig AC (2012). Characterization of a cobalt-specific P1B-ATPase. Biochemistry US 51: 7891-7900. DOI: 10.1021/ bi3006708.

Zoller H, Vogel W (2004). Iron supplementation in athletes - first do no harm. Nutrition 20: 615-619. DOI: 10.1016/j.nut.2004.04.006. 